\author{
Dr Arkadiusz SIEROŃ \\ Wydział Prawa, Administracji i Ekonomii, Uniwersytet Wrocławski \\ e-mail: arkadiusz.sieron@uwr.edu.pl \\ ORCID: 0000-0002-5817-8747
}

DOI: $10.15290 /$ oes.2019.02.96.04

\title{
CZY POLSKA WPADŁA W PUŁAPKĘ ŚREDNIEGO DOCHODU?'
}

\begin{abstract}
Streszczenie
Cel - Celem artykułu jest określenie, czy Polska wpadła w pułapkę średniego dochodu.

Metoda badań - Praca wykorzystuje metodę analizy i krytyki piśmiennictwa oraz wnioskowanie.

Wyniki - Przeprowadzone analizy wskazuja, że pułapka średniego dochodu nie ma potwierdzenia ani w teorii, ani w empirii - zwłaszcza w odniesieniu do Polski. Według większości kryteriów, Polska z PKB per capita powyżej 28 tys. USD nie wpadła w pułapkę średniego dochodu. Koncept ten nie powinien zatem wpływać na politykę gospodarczą. Rekomendacje dla polityki gospodarczej wysuwane na podstawie hipotezy pułapki średniego dochodu nie będą bowiem właściwe, a mogą nawet przynosić przeciwny skutek.
\end{abstract}

Słowa kluczowe: Polska, transformacja, pułapka średniego dochodu

\section{HAS POLAND FALLEN INTO A MIDDLE-INCOME TRAP?}

\begin{abstract}
Summary
Purpose - The aim of the study is to determine whether Poland has fallen into a middle-income trap.

Research method - The article uses a critical appraisal of literature and reasoning.

Results - The analysis carried out indicate that both the theoretical and empirical foundations of the middle-income trap are very weak. Even if we assume that the trap exists, Poland, with GDP per capita amounting to above $\$ 28,000$, luckily hasn't fallen into it, according to most criteria. Hence, that concept should not guide the country's economic policy. The recommendations for economic policy put forward on the basis of the middle income trap hypothesis will not be appropriate, and may even be counterproductive.
\end{abstract}

Key words: Poland, transformation, middle-income trap

JEL classification: F43, F63, O10, O40

1 Artykuł wpłynął 12 października 2018 r., zaakceptowano 10 grudnia 2018 r.

Article received 12 October 2018, accepted 10 December 2018. 


\section{Wprowadzenie}

Porównania międzynarodowe pokazują, że krajowa transformacja gospodarcza okazała się sukcesem. Polska istotnie zmniejszyła dystans cywilizacyjny do krajów Zachodu. Ponieważ rozwój polskiej gospodarki w ostatnich trzech dekadach był wspierany przez czynniki wzrostu charakterystyczne dla okresu transformacji, ekonomiści obawiają się spowolnienia wzrostu gospodarczego w przyszłości. Niektórzy badacze piszą o wyczerpywaniu się prostych rezerw wzrostu, jednak inni idą dalej i twierdza, że Polska bądź już wpadła, bądź też grozi jej wpadnięcie w pułapkę średniego dochodu [Pruchnik, Toborowicz, 2014; Pruchnik, Zowczak, 2016; Radło, Ciesielska, 2013; Staniłko, 2013].

Nie tylko ekonomiści, ale także członkowie administracji publicznej zaczęli odwoływać się do pojęcia pułapki średniego dochodu [Szydło, 2015] - została ona nawet uznana za jedna z barier rozwoju Polski w Strategii na Rzecz. Odpowiedzialnego Rozwoju do roku 2020 (z.perspektywa do 2030 r.) [2017]2.

Celem artykułu jest analiza pojęcia pułapki średniego dochodu i określenie, czy polska gospodarka w nią wpadła lub może w nią wpaść w najbliższej przyszłości. Przedmiotem rozważań są: pojęcie pułapki średniego dochodu, teoretyczne argumenty za i przeciw jej istnieniu oraz odniesienie zagadnienia do Polski.

\section{Na czym polega pułapka średniego dochodu?}

Termin „pułapka średniego dochodu” (ang. middle-income trap) został po raz pierwszy użyty przez I. Gilla oraz H. Kharasa $[2007]^{3}$, którzy bazowali na wcześniejszej pracy G. Garretta [2004]. Intencją autorów było zwrócenie uwagi na brak satysfakcjonującej teorii wzrostu, odnoszącej się do krajów o średnim dochodzie, i przypomnienie, że przeszłe sukcesy nie gwarantuja przyszłych. Jak tłumaczyli lata później I. Gill i H. Kharas [2015], ukuty przez nich termin nie odzwierciedlał deterministycznego przekleństwa krajów o średnim dochodzie, lecz dylematy stojące przed decydentami politycznymi, opracowującymi strategie gospodarcze (oraz pomyłki przez nich popełniane). Od tamtego momentu spotkał się on ze znacznym zainteresowaniem wśród ekonomistów i polityków, znacznie ewoluując, choć w literaturze wciąż brak jednolitej definicji. Ogólnie rzecz biorąc, pułapka średniego dochodu oznacza długookresowe spowolnienie wzrostu gospodarczego, przychodzące po okresie relatywnie szybkiego rozwoju, w wyniku czego kraj, który wpadł

2 W 2017 r. M. Morawiecki, ówcześnie wicepremier oraz minister finansów i rozwoju, określił pułapkę średniego dochodu jako jedną z głównych zidentyfikowanych pułapek w polskiej gospodarce [Biuro Komisji Sejmowych, 2017].

3 A. Wojtyna [2016] słusznie zauważa, że lepszym terminem - ponieważ unika skojarzeń z problematyką nierówności dochodowych - jest „pułapka średniego poziomu rozwoju”. Ze względu jednak na jego rozpowszechnienie, w artykule przyjmuje się pojęcie „,pułapka średniego dochodu”, przy zastrzeżeniu, że odnosi się je do kwestii rozwoju, nie podziału dochodu. 
w taką pułapkę, nie jest w stanie dogonić krajów wysokorozwiniętych [Ciesielska, Radło, 2014; Fic i in., 2016]. Jest to zatem sytuacja, w której, po osiagnięciu średnich dochodów, tempo wzrostu gospodarczego hamuje, co uniemożliwia (lub znacząco spowalnia) proces konwergencji.

Różni autorzy odmiennie definiują i wyjaśniają pułapkę średniego dochodu. Wyczerpujący przegląd literatury można znaleźć w opracowaniu I. Gill oraz H. Kharas [2015]. Interpretacje można podzielić na ilościowe oraz jakościowo-deskryptywne. Jeśli chodzi o pierwsza grupę definicji, to łączą one pułapkę z pewnymi programami rozwoju: a) absolutnymi, b) względnymi lub c) czasowymi. W tym podejściu uważa się, że dany kraj wpadł w pułapkę średniego dochodu lub może wpaść, jeśli: a) jego PKB per capita osiagną określony poziom ${ }^{4}$, b) proces jego konwergencji w stosunku do wybranego kraju wysokorozwiniętego (np. USA) zahamował ${ }^{5}$, c) odpowiednio długo przebywał w określonym przedziale PKB per capita ${ }^{6}$.

Z kolei podejście jakościowo-deskryptywne skupia się na opisowych interpretacjach oraz akcentowaniu najważniejszych czynników spowalniających wzrost gospodarczy. Do takich przyczyn najczęściej zalicza się niską innowacyjność („,pułapkę imitacj’”), niekorzystne trendy demograficzne, niską wartość dodaną w produkcji (niska pozycję w międzynarodowym łańcuchu wartości), zahamowanie wzrostu produktywności ze względu na zakończenie transferu siły roboczej z rolnictwa do przemysłu oraz niskie płace?

\section{Czy istnieje pułapka średniego dochodu?}

Choć koncepcja pułapki średniego dochodu cieszy się powodzeniem zarówno wśród ekonomistów, jak i decydentów politycznych, jej status ontologiczny jest wątpliwy. Prawdą jest, że wiele krajów napotyka liczne bariery rozwojowe. Kraje o średnim dochodzie nie są tutaj wyjątkiem - zaś teza, że muszą one mierzyć się ze specyficznymi problemami dla ich poziomu rozwoju ${ }^{8}$, jest raczej niekontrowersyjna, by

4 Na podstawie analizy empirycznej danych z lat 1957-2007, B. Eichengreen i in. [2011] uważaja, że spowolnienie gospodarcze następuje po osiagnieciu PKB per capita około 16,7 tys. dolarów (w cenach z 2005 r.). M.S. Aiyar i in. [2013] granice pomiędzy państwami o średnim dochodzie i wysokim dochodzie, której przekroczenie jest tak trudne, ustalili na poziomie 15. tys. dolarów amerykańskich (w cenach z 2005 r.). Z kolei M. Spence [2011] pokazał, że od 1975 r. tylko kilku krajom udało się przekroczyć poziom 10 tys. dolarów amerykańskich (w cenach z 2005 r.).

5 P.Ch. Athukorala i W.T. Woo [2011] definiują kraje o średnim poziomie rozwoju, gdy ich PKB per capita odpowiada od 20 do 55\% poziomu USA. Z kolei M. Bukowski i in. [2012] uważają, że jest to poziom między 50 a 70\% amerykańskiego PKB per capita.

6 J. Felipe i in. [2012] wskazują, że kraj wpada w pułapkę średniego dochodu, jeśli nie rośnie na tyle szybko, aby przebić granicę średniego dochodu w ciagu 28 lat oraz granicę wyższego średniego dochodu w ciagu 14 lat.

7 I. Gill i H. Kharas [2007] uważali, że kraje o średnim dochodzie nie są w stanie konkurować zarówno z ubogimi krajami o niskich kosztach pracy, jak i z krajami o wysokim dochodzie, które przoduja w innowacjach. Sugerowałoby to, że problemem są częściowo za wysokie płace.

8 W literaturze podkreśla się konieczność konkurowania zarówno z krajami ubogimi, które maja przewagę kosztową, jak i z krajami wysokorozwiniętymi, które są znacznie bardziej innowacyjne. 
nie powiedzieć banalna. Nie wynika z tego jednak, że kraje o średnim dochodzie są jakoś szczególnie podatne na osłabienie wzrostu gospodarczego?.

Istotnie, badania empiryczne dają niejednoznaczne rezultaty. Choć - jak wykazano w poprzedniej części artykułu - niektóre prace sugerowały istnienie pułapki średniego dochodu [Im, Rosenblatt, 2013; Felipe i in., 2014; The middle-income trap has..., 2017; Bulman i in., 2017; Aslund, 2018; Yavuz-Tiftikcigil i in., 2018] nie udało się tego wykazać.

Przed rozważaniami na temat, czy Polska wpadła w pułapkę średniego dochodu, warto zbadać istotę samego pojęcia na gruncie teoretycznym. Krytyczna analiza unaocznia liczne problemy związane z tą koncepcja.

Po pierwsze, samo istnienie krajów o wysokich dochodach falsyfikuje pułapkę średniego dochodu - musiały one wszak w przeszłości wydźwignąć się ze średniego do wysokiego poziomu dochodów ${ }^{10}$. D. Bulman i in. [2017] wskazują na kraje, które wyrwały się z poziomu średniego dochodu i stały się bogate. Analiza tych przypadków nie potwierdziła wystapienia systematycznej stagnacji podczas tego procesu przeciwnie, kraje te utrzymywały szybki wzrost cały czas aż do osiagnięcia wysokiego dochodu. Z kolei kraje, które nie przekroczyły granicy wysokich dochodów, odnotowywały wolniejsze tempo wzrostu gospodarczego przy każdym poziomie dochodu.

Po drugie, istnieja poważne problemy definicyjne, które podważają sensowność koncepcji. Przede wszystkim nie jest oczywiste, gdzie przebiega granica między krajami o średnim oraz o wysokim dochodzie (jak też o niskim i średnim dochodzie). Im szerzej progi zostaną ustalone, tym więcej państw „utknie” w pułapce średniego dochodu ${ }^{11}$.

Trzeba pamiętać, że obecne kraje o wysokim dochodzie stały się bogate już kilkadziesiąt lat temu. Czy wobec tego powinno się brać pod uwagę dochody państw bogatych osiagane obecnie czy w przeszłości?

Warto zauważyć, że PKB per capita to bardzo ważny miernik gospodarczy, ale nie oddaje w pełni skali rozwoju i może przeszacowywać rozumiany szerzej dystans cywilizacyjny krajów o średnim dochodzie od państw bogatszych - w przypadku

Kraje o średnim dochodzie nie mogą już konkurować niskimi płacami, ale jeszcze nie są wystarczająco innowacyjne. Odnoszę się do tego argumentu później w głównym tekście.

9 Podobnie $\mathrm{z}$ tego, że wzrost gospodarczy w niektórych krajach o średnim dochodzie spowolnił, nie wynika jeszcze, że istnieje prawidłowość uniemożliwiająca przejście krajów od średniego do wyższego dochodu.

10 Podobnie D. Lal [2015] zauważa, że koncepcja pułapki ubóstwa kłóci się z rzeczywistością.

11 Taki zarzut właśnie formułuje się w The middle-income trap has little evidence going for it [2017] wobec raportu Banku Światowego oraz chińskiego Centrum Badawczego ds. Rozwoju [China 2030..., 2013]: Użyte w nim kryteria średniego dochodu są zbyt szerokie, aby mogły być przydatne. Zgodnie z zawartą w nim definicją kraj z PKB zaledwie 590 dolarów na osobę (według cen z 1990 r.) był uznawany za kraj o średnich dochodach w 1960 r. Obejmuje to takie kraje, jak Chiny podczas Wielkiego Głodu. Na drugim biegunie znajduje się kraj z PKB wynoszącym 13300 dolarów w 2008 r., również zaliczany do krajów o średnich dochodach. Ten górny próg w 2008 r. jest o ponad 2000\% wyższy niż niższy próg dla 1960 r. Nic zatem dziwnego, że tak wiele krajów utknęło pomiędzy tymi progami. 
wielu niedochodowych wskaźników (np. przeciętna oczekiwana długość życia w momencie narodzin) występuje większa konwergencja [Deaton, 2016]. Co więcej, wiele państw o średnim dochodzie cieszy się obecnie wieloma dobrami niedostępnymi dla państw bogatych, gdy znajdowały się w przeszłości na podobnym poziomie [Piatkowski, 2013].

Nie jest również jasne, czy powinno się brać pod uwagę dochody absolutne, czy względne. Zastosowane podejście może dać odmienne rezultaty. Dany kraj może się przecież rozwijać i osiagać coraz wyższy dochód, ale jeśli będzie to czynił w podobnym tempie co Stany Zjednoczone, które służą często za punkt odniesienia ${ }^{12}$, to konwergencja może nigdy nie nastąpić ${ }^{13}$. Mimo osiagania coraz wyższego dochodu narodowego i poprawy poziomu życia obywateli, w relatywnym ujęciu taki kraj będzie wydawał się tkwić w pułapce średniego dochodu.

W dużej mierze takie zjawisko zachodziło w latach 1960-2010. Jak podaje A. Deaton [2016], kraje biedniejsze nie rozwijały się w tym czasie szybciej niż kraje bogatsze. Jednak na całym świecie doszło w analizowanych latach do istotnego wzrostu gospodarczego oraz redukcji ubóstwa - tylko kilka krajów doświadczyło regresu.

Absolutne ujęcie też ma wady. Ostatecznie każde państwo - jeśli tylko notuje pozytywne tempo wzrostu - kiedyś osiagnie wysoki dochód. Czy można zatem mówić o pułapce? Z kolei F.G. Im i D. Rosenblatt [2013] wskazuja, że, używając podejścia absolutnego, można dojść do wniosku, że kraje należące obecnie do G7 pozostawały w pułapce średniego dochodu przez większość XX w., co podważa sensowność tej koncepcji.

Kolejny problem wiąże się z określeniem tego, co to znaczy „utknąć w pułapce średniego dochodu". Jak długo dany kraj musi pozostawać na średnim poziomie rozwoju, aby móc z pewnością stwierdzić, że nie przeżywa on przejściowych problemów albo że nie zaczął po prostu wolniej konwergować, lecz że wpadł w pułapkę? Biorąc pod uwagę relatywnie krótki okres będący przedmiotem analizy, to, co wielu ekonomistów bierze za tkwienie w pułapce średniego dochodu, może być w rzeczywistości jedynie wolniejszą ścieżką konwergencji [Im, Rosenblatt, 2013] ${ }^{14}$.

W kontekście pułapki średniego dochodu często przywołuje się badanie B. Eichengreena i in. [2011], którzy analizowali szybko rozwijające się gospodarki, które w późniejszym czasie doświadczyły długotrwałego spowolnienia. Badacze ci brali pod uwagę kraje, których PKB per capita był wyższy niż 10000 USD w cenach z 2005 r. i które przed spowolnieniem rosły w ciagu 7 lat przeciętnie co najmniej $3,5 \%$ rocznie, a po spowolnieniu tempo wzrostu obniżyło się o co najmniej 2 p.p.

12 Ciekawym pytaniem jest o właściwy punkt odniesienia w czasach przed rewolucją przemysłową, gdy wszystkie państwa pozostawały ubogie.

13 Być może zatem lepszym określeniem w takim przypadku byłaby „pułapka braku konwergencji”?

14 Pułapka średniego dochodu bywa mylona nie tylko $\mathrm{z}$ wolną konwergencja, ale także $\mathrm{z}$ prostym efektem doganiania. Zgodnie z nim, kraje biedniejsze mogą rozwijać się szybciej niż bogatsze dzięki transferowi technologii oraz zjawisku malejącej produktywności kapitału. Wolniejszy rozwój krajów o średnim dochodzie od państw ubogich nie powinien zatem dziwić i stanowić przesłanki do wysuwania hipotez o wpadnięciu w pułapkę średniego dochodu. 
w siedmioletnim okresie. Ich analiza wykazała, że spowolnienie następowało przeciętnie po osiagnięciu PKB per capita około 16,7 tys. dolarów (w cenach z 2005 r.).

Trzeba jednak zwrócić uwagę na ważne implikacje warunków przyjętych przez badaczy. Ograniczenie analizy do krajów o PKB per capita powyżej 10 tys. dolarów nie pozwala określić, czy kraje o średnim dochodzie są wrażliwsze na zahamowanie wzrostu od państw ubogich. Z kolei przyjęcie tempa wzrostu co najmniej 3,5\% rocznie wyklucza wiele bogatych gospodarek, które rzadko rosną tak szybko. Wreszcie obniżenie tempa wzrostu gospodarczego o 2 p.p., choć bolesne, może nie być wystarczające, aby stworzyć pułapkę dla gospodarki - spadek tempa wzrostu z 10\% do 8\% wciąż pozwalałby danemu krajowi (np. Chinom) na konwergencję do państw bogatych [The middle-income trap has..., 2017].

Z koncepcja pułapki średniego dochodu wiążą się nie tylko problemy definicyjne. Główny argument, wyjaśniający to zjawisko głosi, że kraje o średnich dochodach nie sa już konkurencyjne pod względem płac, a jednocześnie nie osiagnęły jeszcze wysokiego poziomu zaawansowania technologii. Znajdują się zatem między krajami o niskich dochodach i płacach a państwami o wysokich dochodach i umiejętnościach. Zarówno strategie wzrostu, bazujące na taniej produkcji przemysłowej, jak i te zakładające produkcję wysoko innowacyjnych produktów będa nieodpowiednie dla krajów o średnim dochodzie. Błąd tutaj tkwi w zbyt holistycznym ujęciu. Powyższe podejście zakłada implicite, że każdy kraj realizuje jakąś jedną ogólnonarodową strategię gospodarcza. W tej perspektywie rzeczywiście mogą pojawić się problemy przy przejściu z jednego do drugiego etapu. W rzeczywistości jednak wzrost nie przebiega „w oddzielnych etapach, które wymagaja ogólnonarodowego przejścia" [The middle-income trap has..., 2017]. W każdej gospodarce realizowanych jest wiele różnych strategii gospodarczych. Istnieją zarówno firmy wysoko innowacyjne, jak i takie, które stawiają na imitację oraz niskie płace. Oznacza to, że firmy wewnątrz krajów znacznie różnią się pod względem produktywności [Bartelsman i in., 2008] ${ }^{15}$. Zatem kraje o średnich dochodach moga konkurować zarówno z krajami biednymi, jak i bogatymi, ponieważ na ich terenie operują firmy o różnych modelach biznesowych.

Warto również zauważyć, że płace i poziom innowacyjności (umiejętności, technologia) nie są zmiennymi zerojedynkowymi. Kraje o średnim dochodzie moga zatem łączyć przeciętne płace z przeciętnym poziomem umiejętności, technologii i produktywności - i w ten sposób konkurować z krajami na innym poziomie rozwoju [The middle-income trap has..., 2017].

15 Zjawisko takie zachodzi również w Polsce. A. Laszek i in. [2015] wskazują, że produktywność dużych przedsiębiorstw (zatrudniających 250 osób i więcej) jest już bardzo zbliżona do poziomu zachodnioeuropejskiego, podczas gdy produktywność na jednego zatrudnionego w mikroprzedsiębiorstwach wynosi tylko około $1 / 3$ poziomu zachodnioeuropejskiego. Ponadto w kraju występuje znaczne zróżnicowanie produktywności firm działających w różnych sektorach gospodarki. 


\section{Pułapka średniego dochodu - przypadek Polski}

Z pułapką średniego dochodu wiążą się (jak wskazano w poprzedniej części artykułu) problemy empiryczne oraz teoretyczne, które stawiają sensowność tej koncepcji pod znakiem zapytania - zatem, czy Polska wpadła lub może wpaść w pułapkę średniego dochodu?

Jak widać na rysunku 1, PKB per capita w Polsce w 2017 r. wyniósł ponad 28 tys. dolarów amerykańskich ( $w$ cenach z 2016 r.). Nawet po przeliczeniu na dolary z 2005 r., Polska klasyfikowałaby się jako kraj o wysokim dochodzie - i to według wszelkich kryteriów. Istotnie już w 2011 r. OECD i Bank Światowy zmieniły klasyfikację Polski z „kraju o wyższych średnich dochodach” na „kraj o wysokich dochodach”. Jeśli chodzi o ujęcie względne, to Polska wciąż może utkwić w pułapce średniego dochodu według niektórych definicji, np. M. Bukowskiego i in. [2012]. Warto jednak zauważyć, że stosunek polskiego PKB per capita względem poziomu amerykańskiego systematycznie rósł od początku lat 90 ., tj. wzrastając z $27,5 \%$ do $48,6 \%$ w przeciagu zaledwie 25 lat. Taka dynamika odpowiada bardziej ciagłej konwergencji aniżeli spowolnieniu gospodarczemu, skutkującemu utknięciem w pułapce rozwojowej.

\section{RYSUNEK 1}

\section{PKB per capita Polski - wymiar absolutny (w \$, ceny z 2016 r.) i relatywny (jako \% PKB per capita USA) w latach 1950-2017}

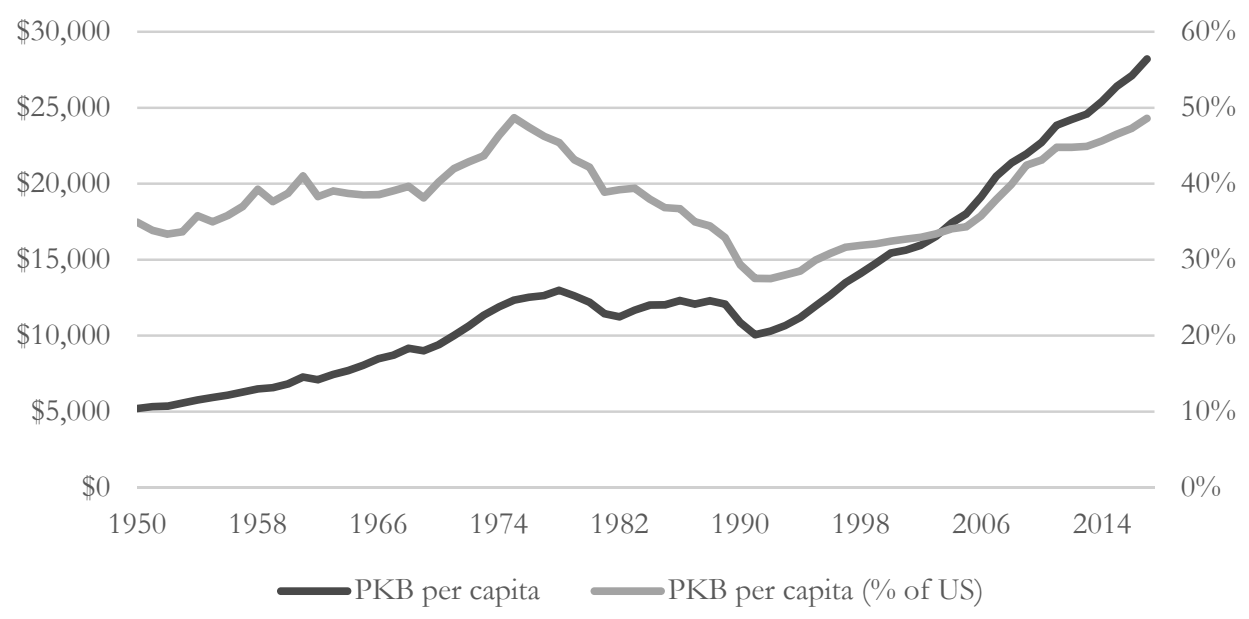

Źródło: opracowanie własne na podstawie: [Output, Labor..., 2018].

Oczywiście, przeszłe wyniki nie determinuja przyszłego tempa wzrostu gospodarczego (co zresztą stanowi argument przecinvko determinizmowi tkwiącego u podstaw pułapki średniego dochodu). Polska gospodarka mogła rozwijać się tak szybko dzięki wzrostowi wydajności pobudzanego przez transformację gospodarczą. Jednak 
wraz z upływem czasu pewne względnie proste motory wzrostu, takie jak: realokacja zasobów pomiędzy sektorami, usuwanie marnotrawstwa, przenoszenie rozwiązań organizacyjnych oraz transfer technologii, ulegaja wyczerpaniu. Do tego społeczeństwo polskie starzeje się, co może negatywnie oddziaływać na rynek pracy oraz finanse publiczne. Obawy o dalsze tempo wzrostu gospodarczego wydają się zatem uzasadnione.

\section{RYSUNEK 2}

\section{Struktura zatrudnienia w Polsce w latach 1991 i 2017}

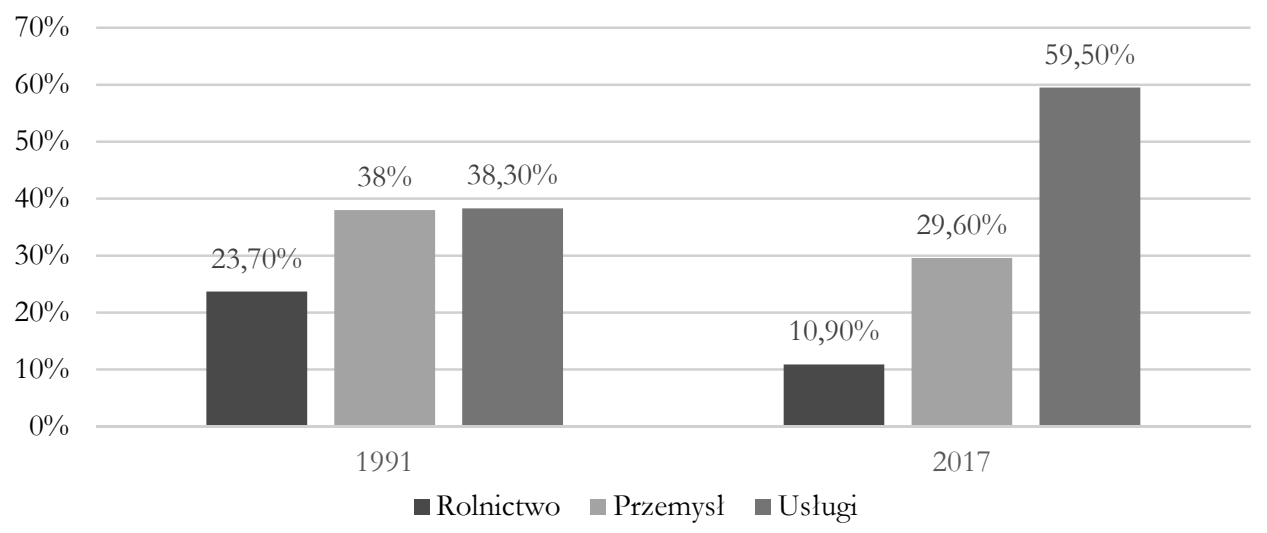

Źródło: opracowanie własne na podstawie: [The World Bank Group, 2019, 2019a, 2019b].

Trzeba jednak zastanowić się, czy można zastosować koncepcję pułapki średniego dochodu do Polski, nawet jeśli pominie się fakt, że jest ona klasyfikowana już jako państwo wysokorozwinięte. Ekonomiści odnosili pierwotnie pojęcie pułapki do krajów, które dynamicznie się rozwijały dzięki przechodzeniu z produkcji rolniczej do produkcji przemysłowej. B. Eichengreen i in. [2011] pisza, że spowolnienie następuje, kiedy przestaje być możliwa dalsza poprawa produktywności poprzez transfer siły roboczej z rolnictwa do przemysłu. Według nich, zachodzące wtedy spowolnienie gospodarcze jest w 85\% powodowane przez spadek łącznej produktywności czynników produkcji (TFP). Sprawdźmy, czy ten opis pasuje do Polski. Choć nasz kraj w momencie rozpoczęcia transformacji gospodarczej rzeczywiście odznaczał się rozrośniętym sektorem rolniczym, to jednak był już krajem uprzemysłowionym. Jak widać na rysunku 2, udział zatrudnienia w rolnictwie istotnie malał, ale podobnie było w przypadku przemysłu - natomiast coraz więcej ludzi pracowało w usługach ${ }^{16}$.

16 Nie oznacza to jednak, że zachodził transfer siły roboczej z rolnictwa i przemysłu do usług. J. Tyrowicz i L. van der Velde [2014] sugeruja, że starsze roczniki, pracujące w dwóch pierwszych działach, odchodziły z rynku pracy, natomiast osoby wchodzace na rynek pracy znajdywały zatrudnienie w usługach. 
Mimo że zatrudnienie w rolnictwie istotnie się zmniejszyło w minionym ćwierćwieczu, w Polsce wciąż utrzymuje się przerost zatrudnienia w tym dziale. Ponadto stopa zatrudnienia oraz stopa inwestycji są relatywnie niskie [Nasteppne 25 lat..., 2015]. Nie wydaje się zatem, aby występowało przeinwestowanie, które mogłoby grozić późniejszym załamaniem wzrostu. Wręcz przeciwnie, proste rezerwy wzrostu gospodarczego, które moga przeciwdziałać ewentualnemu spowolnieniu, nie zostały jeszcze całkowicie wyczerpane w Polsce.

Biorąc pod uwage źródła polskiego wzrostu gospodarczego w minionym ćwierćwieczu (rysunek 3), Polska rozwijała się przede wszystkim dzięki wzrostowi łącznej produktywności czynników produkcji oraz dzięki wzrostowi zasobu kapitału.

RYSUNEK 3

Dekompozycja wzrostu gospodarczego w Polsce w latach 1992-2016

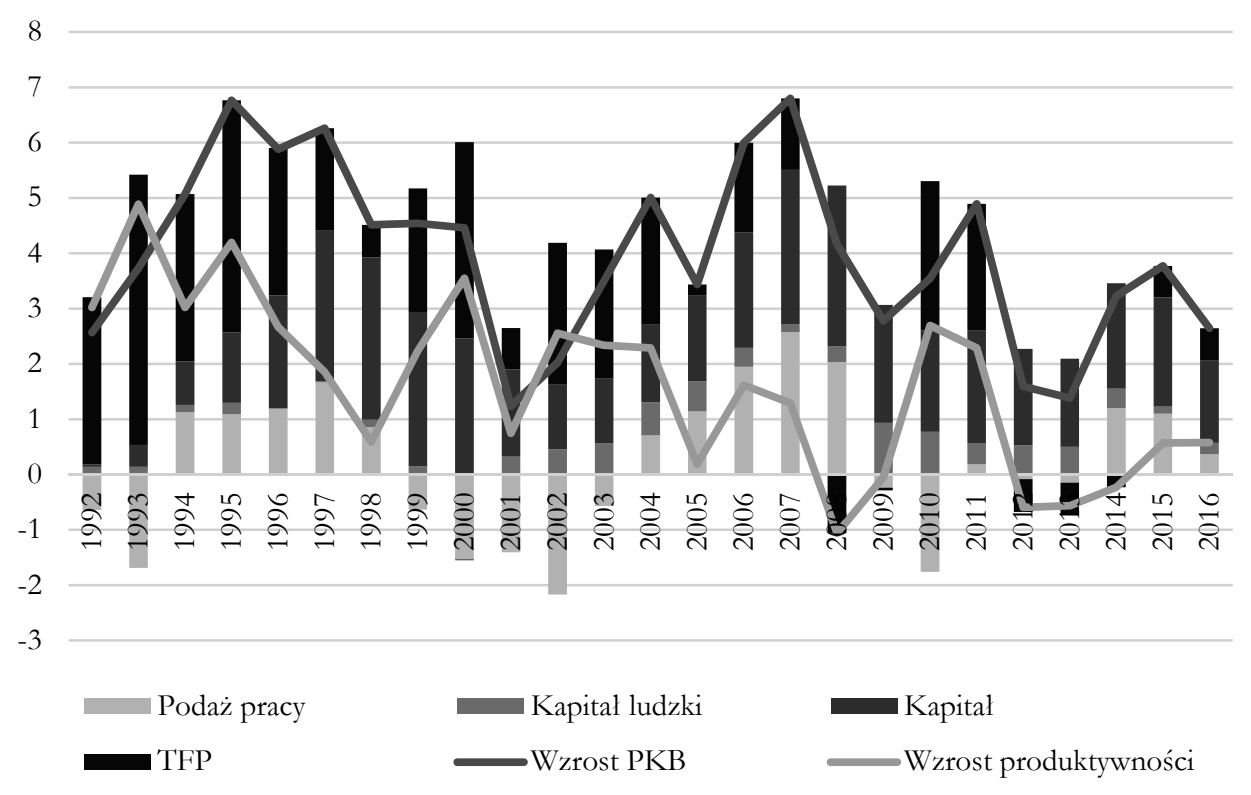

Źródło: opracowanie własne na podstawie: [Growth Accounting..., 2018].

Początkowo wzrost PKB wynikał z restrukturyzacji gospodarki i wynikającego z tego lepszego wykorzystania istniejących czynników produkcji. Jednak tempo wzrostu produktywności, mimo cyklicznych wahań, od lat maleje. Biorąc pod uwagę ograniczoną możliwość dalszych zmian strukturalnych (realokacji czynników produkcji z mniej do bardziej produktywnych sektorów), przy braku odpowiednich reform istnieje ryzyko spowolnienia produktywności. Dotychczas nie widać jednak znacznego załamania wzrostu produktywności, o której pisali B. Eichengreen i in. [2011] - spadek w latach 2008-2009 oraz 2012-2014 wydaje się mieć charakter 
cykliczny, związany z koniunkturą w UE. Co więcej, produktywność pracy na roboczogodzinę wzrasta od 2014 r., zaś jej tempo wzrostu pozostaje od lat wyższe niż w Stanach Zjednoczonych czy w Niemczech (rysunek 4).

\section{Wzrost produktywności pracy (na roboczogodzinę) w Polsce, USA i Niemczech w latach 1994-2017 (w \%)}

8

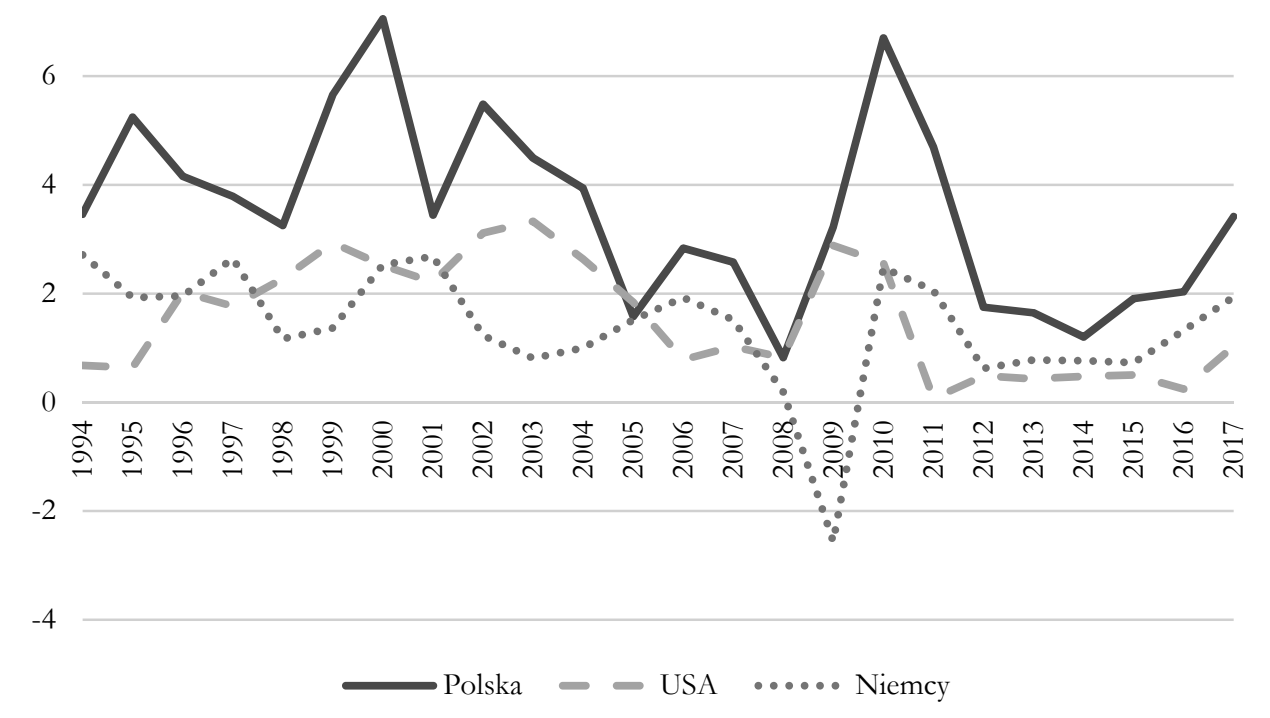

Źródło: opracowanie własne na podstawie: [Output, Labor..., 2018].

Jak zauważa S. Gomułka [2016] oznacza to, że - wbrew wielu opiniom - polska gospodarka jest innowacyjna. W długim okresie miarą innowacyjności gospodarki jest bowiem właśnie tempo wzrostu produktywności pracy. Tymczasem ekonomiści skupiają się na innowacyjności polskiego sektora $B+R$, myląc ją z innowacyjnością całej gospodarki. Często w tym kontekście zwraca się uwagę na relatywnie niewielkie wydatki na badania oraz na względnie niewielki udział zaawansowanych technologii w eksporcie. Trzeba jednak zauważyć, że w latach 1990-2014 udział Polski w światowym eksporcie zwiększył się z $0,45 \%$ do 1,06\%, co dowodzi konkurencyjności polskiej gospodarki. Co istotne, systematycznie zmieniała się struktura eksportu: znaczenie obrotu artykułami surowcowo-rolnymi spadało na korzyść eksportu przetworzonych artykułów przemysłowych. Oznacza to, że wraz ze wzrostem polskiego eksportu ogółem zmniejsza się rola towarów o mniejszym stopniu przetworzenia, zaś zwiększa się waga towarów o wyższym stopniu przetworzenia i żywności. 
Zmalało również znaczenie towarów pracochłonnych na rzecz kapitałochłonnych oraz intensywnych technologicznie. Poprawiła się struktura eksportu produktów przemysłu przetwórczego pod względem zaawansowania technologicznego ${ }^{17}$.

RYSUNEK 5

Udział dóbr wysokiej techniki w polskim eksporcie (w latach 1992-2016)

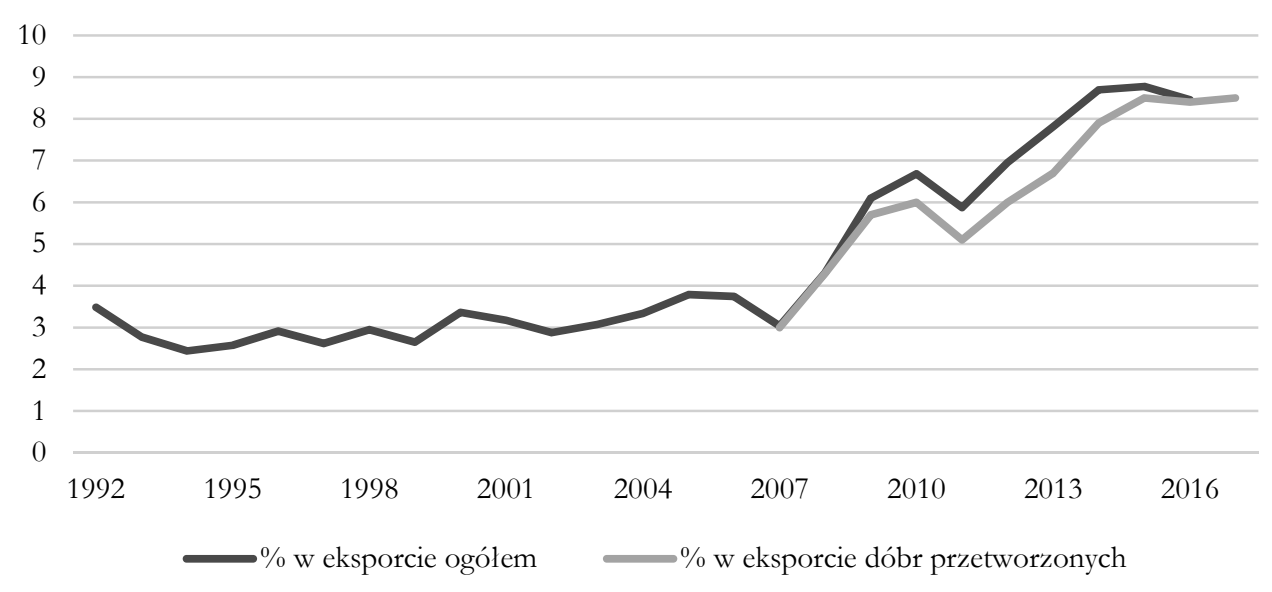

Źródło: opracowanie własne na podstawie: [The World Bank Group, 2019c; Eurostat, 2018]

Głównym źródłem postępu technologicznego w Polsce jest przenoszenie technologii i rozwiązań organizacyjnych z krajów liderów ${ }^{18}$. Jednak trudno, aby było inaczej przy obecnym poziomie rozwoju i udziale w globalnej gospodarce. „Nawet w bogatych krajach, które pozostaja małymi gospodarkami, transfer technologii z zagranicy pozostaje podstawowym źródłem postępu technologicznego" [Nasteppne 25 lat..., 2015, s. 73].

17 Na temat wzrostu zaawansowania technologicznego polskiego eksportu w pierwszej dekadzie XXI w. pisze B. Michalski [2013]. Autor zwraca uwagę, że w latach 2001-2011 zmniejszył się udział surowców i dóbr pracochłonnych z 25,1\% do 15,1\%, zaś udział dóbr o niskim zaangażowaniu kapitału (low-tech) zmalał z 18,4\% do 15,4\% Zwiększył się natomiast udział dóbr o średnim zaangażowaniu kapitału (mid-tech) z $28 \%$ do $32,9 \%$ oraz o wysokim zaangażowaniu kapitału (hightech) z $11,8 \%$ do $17,3 \%$.

18 Istotnie, w indeksach innowacyjności, które uwzględniają absorpcję technologii, Polska wypada znacznie lepiej. Jak zauważa J. Cieślik, istnieje „stereotyp rozpowszechniony nie tylko w Polsce, ale w całej kulturze zachodniej, że imitacja to coś gorszego niż własne oryginalne technologie. Tymczasem (...) z perspektywy przedsiębiorstwa strategia imitacyjna jest nie gorsza, a w wielu wypadkach lepsza niż strategia oparta na oryginalnych rozwiązaniach” [Cieślik, 2015, s. W3]. 


\section{Podsumowanie}

Pojęcie pułapki średniego poziomu rozwoju zadomowiło się zarówno w pracach naukowych z zakresu ekonomii, jak i w dyskursie publicznym. Na podstawie przeprowadzonej analizy nie wydaje się jednak, aby rzucało ono nowe światło na skomplikowane mechanizmy wzrostu gospodarczego. Problem trwałego wzrostu zachodzi zawsze, nie tylko przy średnich dochodach. Termin jest niejasny i wiążą się z nim poważne problemy teoretyczne, zaś postulowane zjawisko nie znajduje potwierdzenia w danych empirycznych - R. Barro [2016] uważa je wprost za mit. Nawet jeśli na potrzeby dyskusji założy się istnienie pułapki średniego dochodu, to - według większości kryteriów - Polska z PKB per capita powyżej 28 tys. USD nie wpadła w nia.

$\mathrm{Na}$ podstawie przeprowadzonej analizy można wyciagnąc kilka istotnych wniosków - zarówno dla teorii ekonomii, jak i dla polityki gospodarczej.

Po pierwsze, kwestia pułapki średniego dochodu pokazuje niebezpieczeństwo używania metaforycznego języka w debacie naukowej. Barwne zwroty są interesujące i przyciagają uwagę, jednak często bardziej zaciemniają niż wyjaśniają rzeczywistość gospodarczą. Ekonomiści i decydenci polityczni wiele mówią o pułapce średniego dochodu, jednak rzadko tłumacza, co mają dokładnie na myśli. Wielość interpretacji tego pojęcia i brak precyzyjnej definicji nie sprzyja racjonalnej debacie oraz tłumaczy, dlaczego koncepcja pułapki średniego dochodu wciąż się utrzymuje, mimo braku przekonujących dowodów teoretycznych i empirycznych na jej występowanie.

Po drugie, zwolennicy koncepcji pułapki średniego dochodu zdaja się nie dostrzegać, że wzrost gospodarczy i konwergencja to procesy długotrwałe. To, co biora za tkwienie w pułapce, może być jedynie powolnym dołączaniem do krajów bogatszych. Wieloletnie - by nie powiedzieć wielowiekowe - zacofanie gospodarcze nie może zostać odrobione w ciagu jednej nocy. Dwieście lat współczesnej gospodarki to relatywnie niewiele. Według obecnych, absolutnych kryteriów dochodowych, kraje należące do $\mathrm{G} 7$ pozostawały na średnim poziomie rozwoju przez większość XX w. [Im, Rosenblatt, 2013]. Powolny wzrost gospodarczy słusznie może niepokoić, ale formułowanie fałszywych diagnoz nie pozwala rzetelnie ocenić sukcesów i porażek dotychczasowego rozwoju oraz zaprojektować odpowiednia politykę gospodarczą. M. Piatkowski [2013] wykazał, że lata od transformacji gospodarczej były najprawdopodobniej najlepsze $\mathrm{w}$ ponad tysiącletniej historii Polski. W ciagu niewiele ponad dwóch dekad Polska odrobiła zaległości powstałe przez ponad 500 lat gospodarczej degrengolady ${ }^{19}$. Sugeruje on nawet, że XXI w. będzie kolejnym polskim złotym wiekiem. Nie chodzi o to, aby popaść w samozadowolenie i spocząć na laurach, ale rzetelna analiza osiagnięć Polski od transformacji gospodarczej jest niezbędnym warunkiem sformułowania właściwej diagnozy obecnych wyzwań oraz odpowiednich reform.

19 Według szacunków dochód per capita w Polsce był równy 62\% dochodów w dwunastu wiodących gospodarkach Europy Zachodniej w 1500 r. Od tamtej pory zasadniczo ciagle spadał do zaledwie 35\% w 1989 r. Poziom z 1500 r. udało się osiagnąć dopiero w 2013 r. [Piatkowski, 2013]. 
Wiąże się z tym trzeci wniosek: rekomendacje dla polityki gospodarczej wysuwane na podstawie hipotezy pułapki średniego dochodu nie będą właściwe, a mogą być nawet przeciwskuteczne. Forsowanie narodowej strategii mającej na celu wymuszenie innowacyjności, aby wyrwać się z rzekomej „pułapki średniego dochodu" może paradoksalnie do niej wepchnąć, a w najlepszym przypadku doprowadzić do spowolnienia gospodarczego ${ }^{20}$. Proponowane rozwiązania nie adresują bowiem często rzeczywistych wyzwań, odciagając uwagę od najpilniejszych reform, a bywa, że moga nawet pogłębić problem. Przykładem może być Strategia na Rzecz. Odpowiedzialnego Rozwoju do roku 2020 (zperspektywa do 2030 r.) [2017]. O ile diagnoza problemów zawarta w tym dokumencie jest w dużej mierze prawidłowa, zaś główny cel $\mathrm{w}$ postaci zwiększenia roli innowacji w tworzeniu polskiego PKB (poprzez budowę przyjaznego otoczenia dla firm oraz oszczędności Polaków) wydaje się zasadny, o tyle proponowane rozwiązania są bardziej kontrowersyjne. Wątpliwe jest bowiem, czy państwo jest w stanie budować trwała przewagę konkurencyjną gospodarki poprzez aktywne i selektywne wsparcie tych sektorów. M. Noland i H. Pack [2003], H.J. Kim [1990] oraz J.-H. Yoo [1990] wykazali, że polityka przemysłowa nie przyczyniła się do wzrostu gospodarczego w Japonii czy w Korei Południowej, a nawet, że bez niej rezultaty byłyby lepsze. Niepokoi również koncepcja wzrostu opartego na płacach ${ }^{21}$ - wszak wzrost płac jest efektem, a nie przyczyna wzrostu gospodarczego.

Po czwarte, koncepcja pułapki średniego dochodu zdaje się stanowić echo pulapki ubóstwa oraz kolejne wcielenie krytyki kapitalizmu za brak konwergencji między krajami. Konwergencja jednak występuje - ale między krajami o zbliżonych warunkach instytucjonalnych [Barro, Sala-i-Martin, 1992]. Odpowiednie instytucje, np. prawidłowo funkcjonujący system prawny oraz podatkowy, są niezbędnym warunkiem wzrostu gospodarczego.

Wydaje się zatem, że trafniejszym określeniem - dotyczy to również Polski może być pułapka braku reform (antyreform ${ }^{22}$ ), pułapka opieki socjalnej [Aslund, 2010] czy też pułapka państwa. Większość głównych barier wskazywanych przez przedsiębiorców, takich jak złożoność regulacji podatkowych czy nieefektywna biurokracja, odnosi się bowiem do warunków stwarzanych przez państwo [Sieroń, $2017]^{23}$.

20 Z logicznego punktu widzenia przekonanie o twardej prawidłowości uniemożliwiającej awans do wyższego poziomu rozwoju powinno zniechęcić do podejmowania jakichkolwiek działań.

21 P. Agénor i O. Canuto [2012] uważają, że pułapka średniego dochodu może wynikać z kapitału ludzkiego o niskiej jakości - jeśli płace są niskie, ludzie nie mają motywacji do inwestowania w umiejętności.

22 Bądź też pułapka populistycznej polityki gospodarczej, która - jak pokazują liczne przykłady, w szczególności w Ameryce Łacińskiej - „stanowi w ostatecznym rozrachunku największe zagrożenie dla długoterminowego wzrostu gospodarczego" [Piatkowski, 2013, s. 24].

23 Warto zaznaczyć, że dostrzega się to też w dokumencie Strategia na Ržecz Odponvied rialnego Rožwoju do roku 2020 (zperspektywa do 2030 r.) [2017, s. 25] „Słabość instytucjonalna to czynnik, który w dużej mierze pogłębia skalę negatywnego oddziaływania wszystkich pozostałych barier wzrostu. To właśnie nieefektywne państwo jest w istotnym stopniu odpowiedzialne za brak działań wspierających budowanie polskich oszczędności i kapitału, za brak dążenia do konkurowania wiedza 


\section{Literatura}

Agénor P., Canuto O., 2012, Middle Income Growth Traps, World Bank, Washington. Aiyar M.S., Duval M.R.A., Puy M.D., Wu M.Y., Zhang M.L., 2013, Growth slowdowns and the middle-income trap, International Monetary Fund Working Paper, no. WP/13/71.

Aslund A., 2010, Jak budowano kapitalizm. Transformacja Europy Środkowej i Wschodniej, Rosji i Azji Środkowej, Książka i Wiedza, Warszawa.

Aslund A., 2018, What Happened to the Economic Convergence of Central and Eastern Europe After the Global Financial Crisis?, Comparative Economic Studies, Association for Comparative Economic Studies, vol. 60, no. 2, pp. 254-270.

Athukorala P.Ch., Woo W.T., 2011, Malaysia in the Middle-Income Trap, Asian Economic Panel Meeting, Columbia University, New York City, 24-25 March, 2011.

Barro R., 2016, Economic Growth and Convergence, Applied Especially to China, NBER Working Paper, no. 21872.

Barro R., Sala-i-Martin X., 1992, Convergence, "Journal of Political Economy", vol. 100(2), pp. 22-51.

Bartelsman E.J., Haskel J., Martin R., 2008, Distance to Which Frontier? Evidence on Productivity Convergence from International Firm-Level Data, CEPR Discussion Paper, no. DP7032.

Biuro Komisji Sejmowych, 2017, Pełny zapis przebiegu posiedzenia Komisji Gospodarki i Rozwoju, nr 84, z 14 września 2017 r., http://orka.sejm.gov.pl/zapisy8. nsf/0/9D1CB48CEBE63FF7C12581A7004AAA28/\%24File/0223408.pdf [data wejścia: 6.02.2018].

Bukowski M., Szpor A., Śniegocki A., 2012, Drzemiacy tygrys spetany orzęt. Dylematy polskiej debaty o polityce inwestycyjnej, Instytut Badań Strukturalnych, Warszawa.

Bulman D., Eden M., Nguyen H., 2017, Transitioning from Low-Income Growth to HighIncome Growth: Is There a Middle-Income Trap?, ADBI Working Paper, no. 646, pp. 1-30.

China 2030: Building a Modern, Harmonious, and Creative Society, 2013, Development Research Center of the State Council, World Bank, DOI: 10.1596/978-0-82139545-5.

Ciesielska D.A., Radło M.J., 2014, Determinanty wejscia w pułapke średniego dochodu: perspektywa Polski, „Kwartalnik Nauk o Przedsiębiorstwie”, nr 2, s. 5-13.

Cieślik J., 2015, O pułapkach uychodzenia zpułapki średniego dochodu, „Rzeczpospolita”, 16 marca 2015 r., s. W3.

Deaton A., 2016, Wielka ucieczka. Zdrowie, bogactwo i źródła nierówności, PWN, Warszawa.

Eichengreen B., Park D., Shin K., 2011, When Fast Growing Economies Slow Down: International Evidence and Implications for China, "NBER Working Paper", no. 16919, pp. $1-50$.

i jakością, zamiast tylko kosztami, brak aktywnej polityki demograficznej oraz niski poziom zaufania społecznego, który ma istotne negatywne znaczenie dla prowadzenia działalności gospodarczej". 
Eurostat, 2018, High-tech exports - Exports of high technology products as a share of total exports (from 2007, SITC Rev. 4), 18.06.2019, http://appsso.eurostat.ec. europa.eu/nui/show.do?dataset=htec_si_exp4\&lang=en, [data wejścia: 19.02.2019].

Felipe J., Abdon A., Kumar U., 2012, Tracking the Middle-Income Trap: What is it, Who is in it, and Why?, ADB Economics Working Paper Series, no. 307, pp. 1-59.

Felipe J., Kumar U., Galope R., 2014, Middle-Income Transitions: Trap or Myth?, ADB Economics Working Paper Series, no. 421, pp. 1-28.

Fic M., Fic D. Ropuszyńska-Surma E., 2016, Pułapka średniego dochodu zagrożeniem dla rozwoju gospodarki polskiej, „Studia i Prace WNEiZ US”, nr 44, t. 3, s. 127-139.

Garret G., 2004, Globalization's Missing Middle, "Foreign Affairs", no. 83, pp. 84-96.

Gill I., Kharas H., 2007, An East Asian Renaissance: Ideas for Economic Growth, DC: World Bank, Washington,.

Gill I., Kharas H., 2015, The Middle-Income Trap Turns Ten, Policy Research Working Paper, no.7403, pp. 1-27.

Gomułka S., 2016, Transformacja i rozwój, PWN, Warszawa.

Growth Accounting and Total Factor Productivity, 1990-2017, 2018, The Conference Board Total Economy Database ${ }^{\mathbf{T M}}$, March, https://www.conference-board.org/ data/economydatabase/TED2, [data wejścia: 19.02.2019].

Im F.G., Rosenblatt D., 2013, Middle Income Traps: A Conceptual and Empirical Survey, Policy Research Working Paper, no. 6594, pp. 1-38.

Kim H.J., 1990, Korean Industrial Policy in the 1970s: The Heavy and Chemical Industry Drive, Working Paper, Korean Development Institute, Seoul.

Lal D., 2015, Ubóstwo a postęp, Zysk i S-ka, Poznań.

Michalski B., 2013, Zaawansowanie technologiczne polskiego eksportu w pierwszej dekadzie XXI wieku, „Prace Naukowe Uniwersytetu Ekonomicznego we Wrocławiu”, nr 315, t. 1, s. 607-618.

Następne 25 lat. Jakie reformy musimy przeprowadquí, aby dogonić Zachód?, 2015, Łaszek A., Tatała M., Trzeciakowski R., Wojciechowski W., Olko D., Keler G., Kuskowski J., Paczocha J., Sieroń A., Stachowski J., Zajkowska O. (red.), Forum Obywatelskiego Rozwoju, https://for.org.pl/pl/a/3559,Raport-Nastepne-25-lat-Jakie-reformy-musimy-przeprowadzic-by-dogonic-Zachod [data wejścia: 6.02.2018].

Noland M., Pack H., 2003, Industrial Policy in an Era of Globalization: Lessons From Asia, Institute for International Economics, Washington.

Output, Labor, and Labor Productivity, 1950-2018, 2018, The Conference Board Total Economy Database ${ }^{\mathrm{TM}}$, March, https://www.conference-board.org/data/economydatabase/TED1, [data wejścia: 19.02.2019].

Piatkowski M., 2013, Poland's new golden age: shifting from Europe's periphery to its center, Policy Research Working Paper, no. 6639, http://documents.worldbank.org/ curated/en/285611468107064618/Polands-new-golden-age-shifting-from-

Europes-periphery-to-its-center [data wejścia: 7.02.2018].

Pruchnik K., Toborowicz J., 2014, Low Level of Innovativeness and the Middle Income Trap - Polish Case Study, "Journal of Entrepreneurship Management and Innovation", vol. 10, no. 2, pp. 141-157. 
Pruchnik K., Zowczak J., 2016, Polska transformacja w kontekśscie pułapki średniego dochodu, [w:] Transformacja gospodarcza w Polsce, Geise M., Oczki J., Piotrowski D. (red.), Wydawnictwo Uczelniane Wyższej Szkoły Gospodarki, Bydgoszcz.

Radło M.J., Ciesielska D., 2013, Polska w pułapce średniego dochodu. Perspektyny konkurencyjności polskiej gospodarki i regionów, Difin, Warszawa.

Sieroń A., 2017, Instytucjonalne bariery dla rozwoju przedsiębiorczości w Polsce, [w:] Prawnoekonomiczne szanse i bariery rozwoju pržedsiębiorczości w Polsce i Europie, Stefański M. (red.), Innovatio Press Wydawnictwo Naukowe Wyższej Szkoły Ekonomii i Innowacji, Lublin.

Spence M., 2011, The Next Convergence. The Future of Economic Growth in a Multispeed World, Farrar Straus and Giroux, New York.

Staniłko J., 2013, Czyy Polska może jeszcze wpaść w pułapké średniego dochodu?, Warszawski Instytut Studiów Ekonomicznych, http://wise-europa.eu/2013/11/23/czy-polska-moze-jeszcze-wpasc-w-pulapke-sredniego-dochodu/ [data wejścia: 6.02.2018].

Strategia na Rzecz Odpowiedzialnego Rozwoju do roku 2020 (zperspektywa do 2030 r.), 2017, Uchwała Rady Ministrów z dn. 14 lutego 2017 r., http://www.miir.gov.pl/ media/48672/SOR.pdf [data wejścia: 6.02.2018].

Szydło B., 2015, Exposé premier Beaty Szydto, 18 listopada 2015 r., https://www.premier. gov.pl/expose-premier-beaty-szydlo-stenogram.html [data wejścia: 6.02.2018].

The middle-income trap has little evidence going for it, 2017, The Economist, October 17, https://www.economist.com/special-report/2017/10/07/the-middle-incometrap-has-little-evidence-going-for-it, [data wejścia: 19.02.2019].

The World Bank Group, 2019, Employment in agriculture (\% of total employment) (modeled ILO estimate)," 30.01.2019, https://data.worldbank.org/indicator/SL. AGR.EMPL.ZS?locations=PL, [data wejścia: 19.02.2019].

The World Bank Group, 2019a, Employment in industry (\% of total employment) (modeled ILO estimate), 30.01.2019, https://data.worldbank.org/indicator/SL. IND.EMPL.ZS?locations=PL, [data wejścia: 19.02.2019].

The World Bank Group, 2019b, Employment in services (\% of total employment) (modeled ILO estimate), 30.01.2019, https://data.worldbank.org/indicator/SL. SRV.EMPL.ZS?locations=PL, [data wejścia: 19.02.2019].

The World Bank Group, 2019c, High-technology exports (\% of manufactured exports), 30.01.2019, https://data.worldbank.org/indicator/TX.VAL.TECH.MF. ZS?locations $=$ PL, [data wejścia: 19.02.2019].

Tyrowicz J., van der Velde L., 2014, Can We Really Explain Worker Flows in Transition Economies?, Working Paper, University of Warsaw, Faculty of Economic Sciences, no. 28(145), pp. 1-30.

Wojtyna A., 2016, Kontrowersje teoretyczne wokót koncepcii putapki średniego poziomu rozwoju, „Gospodarka Narodowa”, nr. 286 (6), s. 5-22.

Yavuz-Tiftikcigul B., Guris B., Yasgul Y.S., 2018, Does Middle Income Trap Exist?: Evidence From Emerging Economies: E7 Countries For 1969-2015, "Revista Galega de Economía", vol. 27(1), pp. 145-158.

Yoo J-H., 1990, The Industrial Policy of the 1970s and the Evolution of the Manufacturing Sector, Working Paper, Korea Development Institute, Seoul, no. 9017, pp. 1-140. 